https://helda.helsinki.fi

\title{
Pilgrimage and the becoming of Athonite monasticism
}

\section{Gothoni, Rene}

Routledge, Taylor \& Francis

2020

Gothoni , R 2020 , Pilgrimage and the becoming of Athonite monasticism . in A M Pazos

(ed.), Nineteenth-Century European Pilgrimages : A New Golden Age . 1 edn, Routledge,

Taylor \& Francis , London , pp. 223-240 . https://doi.org/10.4324/9780429198892-16

http://hdl.handle.net/10138/334167

https://doi.org/10.4324/9780429198892-16

unspecified

acceptedVersion

Downloaded from Helda, University of Helsinki institutional repository.

This is an electronic reprint of the original article.

This reprint may differ from the original in pagination and typographic detail.

Please cite the original version. 


\title{
Pilgrimage and the Becoming of Athonite Monasticism
}

\author{
René Gothóni
}

\section{Introduction}

It is well known that Mount Athos is a multinational and pan-Orthodox pilgrimage centre. It is perhaps not equally well known that the becoming of Athonite monasticism was closely connected to pilgrimage as most of the monks originally came as pilgrims. Many of them were refugees, exiles and men on the run, but the majority first came in search of a spiritual father and spiritual advice. In order to understand the characteristics of Athos as a pilgrimage centre it is therefore essential to know something of its history, in other words the becoming of Athonite monasticism.

Consequently, my aim is first to answer the question of how Mount Athos became multinational and pan-Orthodox, second to point out the importance of its hesychastic tradition in periods of decline, crisis and change during the five centuries of Ottoman rule, and finally to show how the renewal of Athonite monasticism and pilgrimage are interconnected.

One should ask of everything that exists at a given time and place what was before and what came after. Thus, in the study of pilgrimage and Athonite monasticism, there are at least three stages of becoming, namely the preceding period, the period in question and the period that followed. ${ }^{1}$

\footnotetext{
${ }^{1}$ René Gothóni, Attitudes and Interpretations in Comparative Religion (Helsinki, 2000), p. 22.
} 


\section{Table $1 \quad$ Stages of becoming}

Past Before The given time After Future

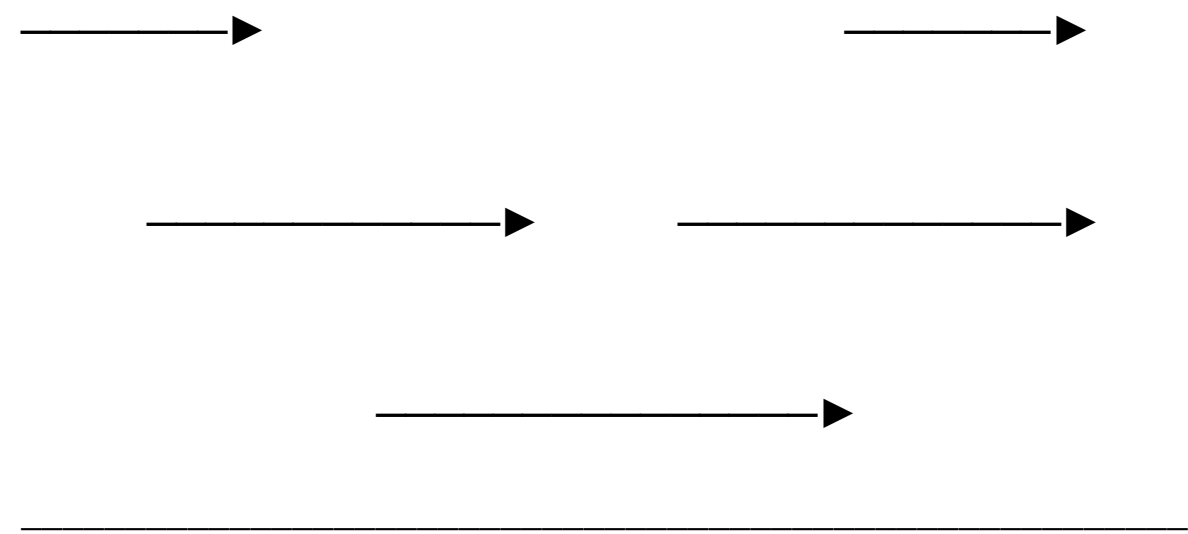

The above-simplified historical perspective shows becoming as a continuous process visualized as a rope: the metaphor illustrates both the complexity and the becoming of any historical process. A rope consists of fibres laid parallel and spun or bunched into yarns. Two or more of these are twisted together to form a strand, and three or more of these strands twisted together produce the rope.

Similarly, a monastery is an entity comprising 'fibres' - read transmitted elements. Paraphrasing Wittgenstein one could say that the strength of the rope - read monastery depends not on the fact that one 'fibre' runs through its entire (historical) length, but on the overlapping of many 'fibres', as illustrated in Table $1 .{ }^{2}$ It is in accordance with these lines of thought that I will analyse the becoming of Athonite monasticism and pilgrimage.

\footnotetext{
${ }^{2}$ Ludwig Wittgenstein, Philosophische Untersuchungen (Oxford, 1967), § 67. Gothóni, Attitudes, pp. 22-23.
} 


\section{How Mount Athos became multinational and pan-Orthodox}

It happened this way. When the iconoclasts had lost their fight against the veneration of icons, St Photios the Great (c. 820-895), Patriarch of Constantinople in the years 858-67 and 877-86, initiated a policy to convert the pagan Slavs in the North and North East, namely Bulgarians, Serbs, Moldovans, and Russians. ${ }^{3}$ In 863, this missionary task was given to two Greek brothers from Thessaloniki, Constantine (d. 869), known as Cyril after he became a monk, and Methodios (d. 885). These brothers, the 'Apostles of the Slavs' as they were called later, knew from childhood the dialect of the Macedonian Slavs around the area of Thessaloniki. Before leaving for their missionary work, they were therefore able to translate the Holy Liturgy of St John Chrysostom, the Psalms and the New Testament into the liturgical language that became known as Church Slavonic. ${ }^{4}$ The missionary work among the Slavs was successful in Bulgaria, Serbia and Russia. The Bulgarian and Serbian rulers as well as Russian pilgrims were among the first to visit some of the ruling monasteries on Athos as pilgrims. ${ }^{5}$ Impressed with what they had seen, they converted to Orthodox Christianity and finally forced the entire top echelon in their respective countries to follow their example. This, briefly, is how these three countries were Christianized and later obtained their respective Patriarchates. ${ }^{6}$

The foundation and settlement of many of the ruling monasteries on Athos coincided with the described spread of Orthodox Christianity to the North West following the fall of Palestine and Sinai into Arab hands. The hermits and monks fled westward. Some of them came by ship to Athos, which was a more or less isolated area at the

\footnotetext{
${ }^{3}$ George Ostrogorsky, History of the Byzantine State (Oxford, 1968), p. 199. Francis Dvornik, The Photian Schism: History and Legend (Cambridge, 1948), p. 432.

${ }^{4}$ René Gothóni, 'Mount Athos During the Last Centuries of Byzantium', in Jan Olof Rosenqvist (ed.), Interaction and Isolation in Late Byzantine Culture (Uppsala, 2004), pp. 57-59.

${ }^{5}$ It seems that no Russian ruler except Putin has ever visited Athos.

${ }^{6}$ Ibid., pp. 58-59.
} 
beginning of the ninth century, and were among the first to colonize the next-toinaccessible steep mountain slopes at the tip of the peninsula. Apart from the Slavs, the Albanians, Amalfitans and Georgians found their way to Athos. It seems that the multinationalism on Athos really was due to the ecumenical attitude of St Athanasios the Athonite. $^{7}$

It is possible to compile from monk Isaiah's diplomatic record, Tale of the Holy Mountain of Athos, which he originally dictated to a secretary in 1489 at the request of the Metropolitan of All Russia, a quite accurate table (Table 2) of the national origins of the monks in the ruling monasteries after the fall of Constantinople in 1453. The question mark after the word Greek in connection with the monasteries of Konstamonitou, Xenophontos, Karakalou, Xeropotamou, Pantokrator and Stavronikita is also indicative of the multinational nature of the Athonite monasteries. It seems that monk Isaiah was not sure whether they were Greek or not, probably due to the high number of monks of different nationalities. The Serbian influence was particularly predominant in the fifteenth century.

The difficult centuries before the fall of the Byzantine Empire were characterized by long-lasting power struggles and wars. The Byzantines waged war with the Venetians and Genoese ships in the Mediterranean, with the Serbian and Bulgarian rulers intruding from the North and, of course, with their archenemies the Turks. Athos provided a haven for refugees in these dire circumstances, especially for exiled and banished bishops and patriarchs, abdicated rulers and other dignitaries, but also for pilgrims and soldiers on the run. ${ }^{8}$

\footnotetext{
${ }^{7}$ Ibid., p. 59

${ }^{8}$ Ibid., p. 59.
} 
Table 2 The ruling monasteries in order of precedence, date of foundation and national origins of the monks in 1489 and today ${ }^{9}$

\begin{tabular}{|c|c|c|c|}
\hline $\begin{array}{l}\text { Monastery in order } \\
\text { of precedence }\end{array}$ & $\begin{array}{l}\text { Date of } \\
\text { foundation in } 1489\end{array}$ & \multicolumn{2}{|c|}{$\begin{array}{l}\text { National origin } \\
\text { and today }\end{array}$} \\
\hline Great Lavra & 963 & Greek & Greek \\
\hline Vatopedi & $972-980$ & Greek & Greek \\
\hline Iviron & ca 980 & Iberian & Greek \\
\hline Chilandar & 1198 & Serbian & Serbian \\
\hline Dionysiou & $1370-1374$ & Serbian & Greek \\
\hline Koutloumousiou & $988 ; 1250$ & Moldavian & Greek \\
\hline Pantokrator & $1350-1400$ & Greek? & Greek \\
\hline Xeropotamou & $10^{\text {th }}$ century & Greek? & Greek \\
\hline Zographou & $10^{\text {th }}$ century & Wallachian & Bulgarian \\
\hline Dochiariou & $10^{\text {th }}$ century & Serbian & Greek \\
\hline Karakalou & 1071 & Greek? & Greek \\
\hline Philotheou & $922-1078$ & Albanian & Greek \\
\hline Simonopetra & $1365-1368$ & Bulgarian & Greek \\
\hline St Paul's & $10^{\text {th }}$ century & Serbian & Greek \\
\hline Stavronikita & $10^{\text {th }}$ cent. and 1540 & Greek? & Greek \\
\hline Xenophontos & 1083 & Greek? & Greek \\
\hline Gregoriou & $14^{\text {th }}$ century & Serbian & Greek \\
\hline Esphigmenou & $10^{\text {th }}$ century & Greek & Greek \\
\hline St Panteleimon & $13^{\text {th }}$ century & Russian & Russian \\
\hline Konstamonitou & $10^{\text {th }}$ century & Greek? & Greek \\
\hline
\end{tabular}

${ }^{9}$ René Gothóni, Tales and Truth. Pilgrimage on Mount Athos Past and Present (Helsinki, 1994), p. 14; p. 28 ; p. 38. 
On the diplomatic level, the Athonites obtained permission to visit the court of Sultan Orhan (d. 1362) in the middle of the fourteenth century. They managed to persuade him to offer his protection to what was already known as the Holy Mountain, and to respect its position as a self-governed monastic republic. This well-timed recognition of the Sultan's power proved successful and of lasting value during the Tourkokratia when the Athonites appealed to the Ottoman rulers' sense of justice and their obligation to continue the tradition established by their grand predecessors. ${ }^{10}$

Following the disintegration of the leading monasteries in Constantinople and the transformation of the Patriarchate to an administrative centre, Athos with its untroubled way of life soon became a recognized spiritual retreat in the Orthodox world and its spreading network of monasteries in the North and North West. This out-of-the-way barren mountain, the towers of its self-sufficient, impregnable fortress-like monasteries enclosing the church in the middle of the courtyard and protecting its inhabitants from the attacks of pirates and other intruders, became a haven par excellence for refuges in Late Medieval times. After the fall of Constantinople in 1453, Athos was the last outpost of Byzantium, a position it has, in many respects, maintained until today. ${ }^{11}$

From a geographical perspective, this outline of how Athonite monasticism became multinational and pan-Orthodox clearly illustrates the spread of Orthodox monasticism and networks of monasteries in the eastern parts of Europe as an Orthodox 'corridor' from Egypt in the South to the northern parts of Finland, a 'corridor' between Western Europe and Central Asia. The geographical position and the mountainous

\footnotetext{
${ }^{10}$ Gothóni, 'Mount Athos', p. 60.

${ }^{11}$ Gothóni, 'Mount Athos', p. 60.
} 
landscape of Athos made it ideal as a resort and a place of both refuge and spiritual revitalization in times of power struggles and robbery. ${ }^{12}$

The multinational and pan-Orthodox character of Athonite monasticism as a pilgrimage centre was only strengthened during the nineteenth and twentieth centuries. Before analysing the decline, the crisis, the change and renewal of Athonite monasticism in this period, I will discuss the birth and basic premises of the so-called hesychastic movement that also flourished during the last centuries of Byzantium.

\section{Hesychasm}

Athos was not only a place of refuge, of otium cum dignitate, as it were, it was also and above all the Garden of the Mother of God devoted to spiritual struggle. It was the renowned spirituality of the Athonite monks that attracted newcomers, exiles, refugees and pilgrims. It was on Athos that the so-called hesychast controversy first arose, and it was also there that the crisis was eventually settled, after four Church Councils.

In brief, this is what happened. St Gregory Palamas (d. 1359), who had donned the habit on Athos in 1316, soon became involved in a theological dispute about a method of prayer that, at the moment of stillness, hesychia, gave those dedicated to prayer an awareness of the uncreated divine light. Palamas strongly defended the small group of monks known as hesychasts who argued that through ceaseless prayer - the recitation of 'Lord, Jesus Christ, have mercy upon me, a sinner' - it was possible to bridge the divine and the human, the spiritual and the physical or corporeal, and become imbued with a sense of divine 'energy', divine uncreated light.

\footnotetext{
${ }^{12}$ For a detailed geographical outline of the Orthodox ‘corridor', see Gothóni, 'Mount Athos', p. 61.
} 
Intellectually St Gregory Palamas was firmly rooted in the monastic tradition of the past, and at the same time, he was a creative theologian. His work shows how Orthodox theology did not cease to be active after the eighth century and the seventh Ecumenical Council. Having meticulously reread what the desert fathers had said about inner tranquillity and the seeking of inner and outer stillness, he found that hesychasm as a spiritual tradition went back to the very beginning of the monastic movement, and that St John Climacus used the word hesychia in the seventh century to indicate a state of inner silence and vigilance, associated particularly with the name of Jesus and the repetition of short prayers. This practice was revitalized under the influence of St Symeon the New Theologian in the eleventh century, and later around 1300 by St George of Sinai, who travelled around the empire and spread the hesychast tradition throughout the Orthodox world. ${ }^{13}$

The prayer of silence is also known as 'the prayer of the heart'. This reason for this is that the invocation of the name Jesus is not merely a repeated recital through the lips or a thought in the mind; it is eventually generated spontaneously by the whole of one's being to the extent that in ceaselessly repeating itself it overwhelms one's whole consciousness. This practice together with breathing exercises and a certain bodily posture induces a state of mind that allows one to experience a vision of the uncreated light such as was once shown to the apostles and prophets at the Transfiguration on Mount Tabor. $^{14}$

A learned monk called Barlaam of Calabria fiercely challenged the claim of the hesychasts in the mid-fourteenth century. He believed it was impossible to know or

\footnotetext{
${ }^{13}$ John Climacus, The Ladder of Divine Ascent (New York, 1982), p. 272. Graham Speake, Mount Athos: Renewal in Paradise (New Haven and London, 2002), pp. 86-88.

${ }^{14}$ Ibid., p. 88. Kallistos of Diokleia, The Power of the Name. The Jesus Prayer in Orthodox Spirituality (Oxford, 2000), pp. 25-26.
} 
experience God in this world, and considered the claim that a method of prayer and a state of ecstasy would allow one to experience visions of uncreated light shockingly materialistic.

Palamas took a mediating view in his explanation of the experience of uncreated light in the controversy that followed. He argued that one needed to make a distinction between God's 'energies' and 'essence', and that humans could experience the 'energies' but not the 'essence'.

This explanation was eventually accepted at the two councils held in Thessaloniki in 1347 and 1351. The stir created by the half-century-long theological dispute put Athos at the very centre of the Orthodox world. Bishop Kallistos argued that it was 'those who emphasized the inner, spiritual values of the Greek Christian inheritance' that gave the oppressed Greek Church the strength to survive the dark centuries of Tourkokratia. In hindsight, it seems evident that it was the hesychasts that provided the inspiration for the compilation of the great anthology of spiritual texts known as Philokalia, first published in Venice in 1782, and hence the spiritual food for the revival that has taken place in the two last centuries and continues. ${ }^{15}$

It was not by accident that Palamas found his persuasive and convincing arguments. He was very familiar with the work of previous generations of scholars. He also knew many of the contemporary hermits personally, and had received first-hand guidance from some of them. Although there are no documents confirming that he also knew St Maximos Kafsokalyvian, one of the most prominent of the ascetics of his time, he must have been familiar with his ideas and practices given that he was famous for his

\footnotetext{
${ }^{15}$ Speake, Mount Athos, pp. 88-89. Gothóni, 'Mount Athos’, p. 62.
} 
miracles and prophesies. It seems that Maximos was as well known in his time as our late Elder Paisios (d. 1994). ${ }^{16}$

It is stated in one of the four surviving accounts of the life of St Maximos that he was able to cast out demons. Theophanes, the hegoumenos of Vatopedi, claims in his account that he had seen St Maximos flying through the air. Nevertheless, all four accounts praise the spiritual gift of Maximos, and it is suggested more than once that he had been transfigured by supernatural light. The biographers describe the light in Palamite terms as 'non-material' and 'divine'. Its nature is not discussed, but the description is consistent with Palamas' conception of the light, whether manifested externally or experienced internally, as 'the uncreated energies of God, the divine glory that God reflected at his Transfiguration on Mount Tabor'. ${ }^{17}$

Palamas consistently emphasized the fact that the conception he put forward was not merely his own personal opinion, and that the distinction was based on the living and shared experience of the hesychast Athonites, a claim the four accounts of St Maximos substantiate. 'Is it not evident', Palamas argues, 'that there is but one and the same divine light: that which the apostles saw on Tabor, which purified souls behold even now, and which is the reality of the eternal blessings to come'. ${ }^{18}$

The significance of Palamas' argument and conception has proved to be lasting in that the generation of monks following the thinking of Maximos represent a true witness to the continuing tradition of living, experiential theology that nowadays, as in the fourteenth century, constitutes the inner reality of the Athonites. This tradition has thus

\footnotetext{
${ }^{16}$ On the spirituality of Elder Paisios, see Elder Paisios of Mount Athos. Spiritual Counsels I. With Pain and Love for Contemporary Man (Thessaloniki, 2007).

${ }^{17}$ Speake, Mount Athos, pp. 92-93.

${ }^{18}$ John Meyendorff, A Study of Gregory Palamas (New York, 1998), p. 151. Speake, Mount Athos, p. 92.
} 
far survived the fall of Constantinople, the challenges of the Ottoman rule and the turbulent years in the later history of Greece. ${ }^{19}$

\section{An unexpected Renaissance}

During the last centuries of Byzantium (1261-1453), and despite the gradual disintegration and inevitable dissolution of the Empire ending with the fall of Constantinople, many of the ruling monasteries experienced what was perhaps their greatest Renaissance so far due to donations and gifts from the Serbian rulers. This is what happened.

The Serbs had already conquered large areas in Macedonia during the reign of the Grand Župan Stefan Nemanja (1170-1196), confiscating Athonite properties in the area and withdrawing the privileges of the monasteries. The Athonites had no option but to submit to the powerful conqueror in order to secure their self-governed status. By immediately entering into an alliance with the Serbian ruler, they managed to maintain their privileges and properties, a policy that also worked later on with the Ottomans. ${ }^{20}$

Tsar Stefan Dušan's sympathies with the Athonites were based partly on the wellestablished practice of the dynasty and partly on his personal aim to build a ByzantinoSerbian Empire. His plan, it seems, was to replace the Greek basileus. To be successful in this aim he needed the support bot of the Greek nobility and especially of the Greek clergy in the conquered areas.

After the conquest of Serres in September 1345, Stefan Dušan sent his logothete Chrysos to Athos to ask the monks to pray for the Serbian ruler and to mention his name

\footnotetext{
${ }^{19}$ Kallistos Ware, 'St Maximos of Kapsokalyvia and Fourteenth-Century Athonite Hesychasm', in Kathigitria: Essays Presented to Joan Hussey on her 80 ${ }^{\text {th }}$ Birthday (London, 1988), p. 430.

${ }^{20}$ A previous version of this and the following paragraphs is in Gothóni, 'Mount Athos', pp. 65-68.
} 
in all the ruling monasteries and in the area of Hierissos. In accordance with their former policy, the Athonites agreed to this plea of recognition. In return for this benevolence Dušan issued a chrysobull in November 1345 - addressed to all ruling monasteries -, which reflects the agreement the Athonites made with him in recognizing him as the ruler in exchange for retaining the privileges they had been granted: independence and the wealth of the monastic communities. The Athonites then recognized the newly established Serbian Patriarchate.

An Athonite delegation headed by the Protos took part in the official proclamation and coronation of the Serbian Tsar in 1346. This was a significant event in the history of both medieval Serbia and Athos, because Dušan promulgated chrysobulls for the ruling monasteries, confirming their acquired privileges, granting new ones, and re-establishing the self-governed status and autonomy of Athos. These became models for all later chrysobulls and agreements the Athonites managed to make during the Tourkokratia and later, and even with the EU.

A year later, in 1347, the new Tsar made a pilgrimage to Athos, together with Empress Jelena and his son Uroš. The purpose was both to cement his friendship with the Athonites and to visit the Holy Mountain where his ancestor Stefan I Nemanja, the celebrated St Symeon of Serbia, had spent his last years. It has been suggested that the main reason for Dušan's prolonged visit to Athos was to seek refuge from the Black Death that was ravaging the Balkans at that time. ${ }^{21}$ This would also explain why he travelled with his family, and why the old rule of avaton, denying the entrance of women to the Holy Mountain, was not implemented and the Empress Jelena was admitted. ${ }^{22}$

\footnotetext{
${ }^{21}$ Mirjana Živojinović, 'De nouveau sur le séjour de l'empereur Dušan à l'Athos', Zbornik Radova Vizantoloskog Instituta 21 (1982): pp. 119-126.

${ }^{22}$ On the rule of avaton, see Ioannis M. Konidaris, The Mount Athos Avaton (Athens, 2003).
} 
Dušan and his family visited all the ruling monasteries and many monastic cottages, kellia, bringing precious gifts with them. During this grand tour of Athos, he also became aware of the economic aspects of monastic life, which he generously supported in the following years. After touring the entire peninsula, the family sojourned in the Serbian monastery of Chilandar. While he was there, Dušan even resolved a prolonged conflict over land holdings between the monasteries of Chilandar and the Bulgarian monastery of Zographou: he ruled in favour of Chilandar and in exchange gave Zographou two villages in the area of the Strymon river as well as granting the monastery fiscal immunity.

During the reign of Dušan many of the ruling monasteries managed to procure for themselves a considerable number of landed holdings in the Balkans. The relationship between the Serbs and the Athonites became so close that a Serbian monk named Antony was elected Protos in $1348 .{ }^{23}$ This more than anything else is evidence of the significance of the alliance between the two parties, an alliance that had its origin in two pilgrimages to Athos: first by Stefan I Nemanja's son, who was tonsured a monk at the monastery of Vatopedi and given the name Savvas, and second, three years later, by Stefan himself, who abdicated and became a monk joining his son on Athos in 1189 under the name of Symeon. ${ }^{24}$

Living conditions in the fourteenth century dictated interaction not only with the surrounding villages but also with the Byzantine Empire as a whole, and especially with the Balkans. Monks frequently travelled to Thessaloniki and Constantinople to sell wood, surplus produce and wine, and to purchase necessary provisions. Moreover, they left

\footnotetext{
${ }^{23}$ On the democratic government of Athos, see René Gothóni, Paradise within Reach. Monasticism and Pilgrimage on Mt Athos (Helsinki, 1993), pp. 20-21

${ }^{24}$ Speake, Mount Athos, p. 67.
} 
Athos for medical treatment, pilgrimage, to attend synods, or to visit godchildren. The Athonites were major landowners of vast estates both within and outside the peninsula, and therefore made what could be considered business trips as they entered into negotiations about the purchase or donation of property and the ownership of land.

Documents from the monastery of Chilandar, for instance, disclose how widely its hegoumenos, Gervasios, travelled in the 1320s to purchase land or conduct other financial affairs. He was in Kaisaropolis in February 1320, in Thessaloniki in November 1322, in Serres in September 1323, and in Thessaloniki again in September 1324 and January 1326. Two months later, he was in Serres, and then revisited Thessaloniki in January 1327 and July $1328 .^{25}$

Women played a significant role in the transactions regarding acts of sale and donation. Most of the acts of sale were uncomplicated. A widow (with or without children), or a woman and her husband, or sometimes two sisters, would sell a field, an orchard, a vineyard or some cottage to wealthy Athonite monasteries such as Chilandar, Iviron and Lavra. The payment was usually in cash, but a certain Irene Panagiotou and her daughter Maria were given a cow and calf in exchange for a field. ${ }^{26}$

The land sold to the Athonites was nearly always near or adjacent to monastic properties purchased earlier. In addition to this kind of simple act of sale, donations were made, many of which were in exchange for a 'fellowship' (adelphaton), and for prayers or commemoration. Fellowship meant that the monastery granted the donor the provision of foodstuff for life. There was also a third alternative of exchange between the donor and

\footnotetext{
${ }^{25}$ Korablev, B. (ed.), Actes de Chilandar II [Actes de l'Athos $5=V V 19$ (1912; pr. 1915)] (repr. Amsterdam, 1975), no. 53, 84, 93, 99, 106-107, 112, 117. Cf. Alice-Mary Talbot, 'Women and Mount Athos', in Anthony Bryer and Mary Cunningham (eds), Mount Athos and Byzantine Monasticism [Publication for the Society for the Promotion of Byzantine Studies 4] (Aldershot, 1996), p. 73.

${ }^{26}$ Lemerle, P., Guillou, A., Svoronos, N., Papachryssanthou, D. (eds), Actes de Lavra II [Archives de l'Athos 8] (Paris, 1977), no. 88, 10-11. Cf. Talbot, 'Women', p. 74.
} 
the monastery. In these cases, the donor charged the Athonites only half the price of the property agreed upon and the other half was to be regarded as a donation in exchange for either adelphaton or commemoration. ${ }^{27}$

\section{Ottoman rule}

The last century of Byzantium gave the Athonites a solid economic basis on which to survive the following five centuries of Ottoman rule. As Abbot Paisy of Chilandar writes in his Tale of the Holy Mountain of Athos, there were four thousand monks registered in the sultan's record, 'but if all the Serbs were included, the total number was about six thousand'. If the records of monk Isaiah from 1489 (8,000 monks) and of Abbot Paisy from 1550 (6,000 monks) are correct, which seem to be the case, the Athonite population decreased by about two thousand within the first sixty years of Ottoman rule. ${ }^{28}$ It is also noteworthy that Serbian monks were still dominant and the decrease in numbers mainly concerned other nationalities.

Abbot Joachim of St Panteleimon's account seems to belong to the same literary genre as those of monk Isaiah and Abbot Paisy. He was clearly familiar with the previous records and therefore aimed to give a more comprehensive and up-to-date picture in 1560. According to him there were 2,831 monks living in the ruling monasteries. He does not mention the dependencies, where many must have resided in order to look after the vineyards, olive trees and other produce that was cultivated to fund tax payments. In addition, a number of the monks lived temporarily on farming lands (metóchia) outside the peninsula in mainland Greece or the Balkans. ${ }^{29}$

\footnotetext{
${ }^{27}$ Talbot, 'Women', pp. 74-77.

${ }^{28}$ Gothóni, Tales, p. 28; p. 34.

${ }^{29}$ Ibid., pp. 37-38.
} 
Abbot Joachim records an increase of 685 monks in the ruling monasteries during the first century of Ottoman rule, which could have been partly be attributable to the fact that some of them moved from the dependencies to escape Ottoman pressure and taxation. A closer look at the figures reveals a decline in monk numbers in most of the Greek establishments, however, whereas there was a significant increase in the Balkan, Russian and Slavic monasteries. The expansion was particularly dramatic in Serbia due to Ottoman persecution, as explicitly mentioned in the records of Isaiah, Paisy and Joachim. The Slavic population on Mount Athos increased so much that it clearly outnumbered the Greek population. This development was, of course, the result of the rather recently established good relationship between the Serbian Tsars and the Athonites, and the generous donations of landed properties in Serbia that understandably strengthened the ties. $^{30}$

The lower total numbers of monks given in 1550 and 1560 may reflect the Athonite policy to avoid inequitable ransom and taxation, a tendency Abbot Paisy discloses in his record. Athonites were subject to the Ottoman taxation system from the very beginning of the fall of Constantinople (1453), and Great Lavra and Vatopedi at least quickly became idiorrhythmic in order to cope with the heavy demands.

Before Ottoman rule, all monasteries followed a cenobitic system, which meant that the monks lived a common life in obedience to an abbot, worshipped and ate their meals together as well as contributed any wealth and skills they may have had to the common purse. Under the idiorrhythmic system, on the other hand, the monks were allowed to follow their own way of life, and were not bound by the vow of poverty and obedience to the abbot. In many respects, they lived independently, in separate apartments

\footnotetext{
${ }^{30}$ Ibid., pp. 38-40.
} 
with their own worldly goods and servants. They neither ate together nor contributed to the common purse, and were individually responsible for making ends meet. ${ }^{31}$

The advantage of the idiorrhythmic way of monastic life was that the individual monks were personally responsible for their holdings and what they yielded. They were therefore more inclined to increase production to make ends meet than those in cenobitic monasteries. Given the fixed annual rate of taxation, all excess produce remained at the respective monastery in fairly good conditions despite the economic pressure. In this sense, too, also the monastery benefitted from this 'worldly' system. ${ }^{32}$

A century later John Covel gave an equally informative traveller's account of the conditions in the ruling monasteries in his Athos notes (from 1677). He discusses how much the heavy taxes affected the lives of the monks. Great Lavra and Iviron were the largest monasteries, and Karakalou and Philotheou were apparently in decay. It seems that many of the Greek monks fled to the largest monasteries with extensive farming land, both on Athos and the surrounding island, and on the mainland.

At any one time about one third of the monk population, which then was about six thousand, was abroad engaged in missionary work and or seeking financial and political support against Ottoman pressure. The difficult economic conditions also affected the position of the abbot. This was the case, especially in Lavra and Iviron, where it became the norm to appoint a monk abbot following successful return from missionary and fund-raising work. He stayed in office only one year, however, after which the next recent successful returnee, in accordance with the new tradition, took up the position. Only if the returning monk had failed in his mission did the abbot continue in office.

\footnotetext{
${ }^{31}$ Ibid., pp. 35.

${ }^{32}$ Ibid., pp. 37.
} 
Given this short tenure and the disgrace attached to failure, monks engaged in missionary and fund-raising work did their utmost to succeed. ${ }^{33}$

Covel's account reveals that a few Patriarchs lived in retirement on Athos. Every ruling monastery in the early nineteenth century housed bishops and patriarchs, who had been exiled and banished to Athos, as well as other exiles having decided to end their lives on the Holy Mountain. ${ }^{34}$ Between five hundred and a thousand pilgrims visited the monasteries over Easter in 1677. The exiles proved to be the principal key informants for many travellers' tales and for other foreign pilgrims.

The foreigners were the main source of news from the outside world for the exiles, and they obtained most of their information on Athonite conditions from them. It was an exchange of news and information, a relation that made the life of a recluse more bearable for both parties. However, not all visitors were welcome. One of the most notorious pirates in the Aegean Sea, Captain Crevellier, had been at Lavra just before Covel, and it was obvious that continuing attacks by pirates along with pressure from the Ottoman rulers were sources of great annoyances to the Athonites. ${ }^{35}$

The travellers' tales from the early nineteenth century onwards reflect a decline in monastic life attributable not only to the reduced numbers of monks and poor economic circumstances, but also to a lack of appreciation of the invaluable literary treasures in the monastic libraries. This became the shocking reality for Robert Curzon (d. 1873), Athelstan Riley (d. 1945) and Frederick William Hasluck (d. 1920) in particular: all three went in search of lost Classics, manuscripts and rare books, only to find neglected libraries in poor conditions in nearly all the ruling monasteries. Curzon's description of

\footnotetext{
${ }^{33}$ Ibid., pp. 53-55.

${ }^{34}$ Ibid., pp. 89.

${ }^{35}$ Ibid., pp. 56.
} 
the condition of the library in the monastery of Pantokrator shows the negligence at its worst.

By the dim light which streamed through the opening of an iron door in the wall of the ruined tower, I saw above a hundred ancient manuscripts lying among the rubbish which had fallen from the upper floor, which was ruinous, and had in great part given way. Some of these manuscripts seemed quite entire - fine large folios; but the monks said they were unapproachable, for that floor also on which they lay was unsafe, ... I advanced cautiously along the boards, keeping close to the wall, whilst every now and then a dull cracking noise warned me of my danger, ... At last, when I dared go no farther, I made them bring me a long stick, with which I fished up two or three fine manuscripts, .... When I ... examined them more at my ease, [I] found that the rain had washed the outer leaves quite clean: the pages were stuck tight together into a solid mass, and when I attempted to open them, they broke short off in square bits like a biscuit. Neglect and damp and exposure had destroyed them completely. ${ }^{36}$

Curzon appears to have counted the Greek manuscripts accurately but, as he confesses, he could not examine the Bulgarian, Serbian, Russian, Iberian or Georgian books and manuscripts because he was unversed in those languages. His aim was to purchase as many of them as possible.

Western travellers have often been accused of rifling the libraries of the Near East in particular. This was certainly sometimes the case. However, it is not entirely unjustified to claim that by purchasing manuscripts, travellers managed to save many of those that otherwise would probably have been destroyed and lost forever. A tragicomic event in the monastery of Karakalou is an illustrative case in point. Curzon wrote:

\footnotetext{
${ }^{36}$ Ibid., pp. 101.
} 
As I had found it impossible to purchase any manuscripts at St. Lavra, I feared that the same would be the case in other monasteries; however, I made bold to ask for a single leaf as a thing of some value.

"Certainly!" said the Hegoumenos: "what do you want it for?"

My servant suggested that, perhaps, it might be useful to cover some jam pots or vases of preserves which I had at home.

"Oh!" said the Hegoumenos, "take some more;" and, without more ado, he seized upon an unfortunate thick quarto manuscript of the Acts and Epistles, and drawing out a knife cut out an inch thickness of leaves at the end before I could stop him.

It proved to be the Apocalypse, which concluded the volume, but which is rarely found in early Greek manuscripts of the Acts: it was of the eleventh century ... ${ }^{37}$

Curzon's account also reveals that many of the monastic buildings had fallen into ruins. The sultan continuously increased taxes and prevented the monasteries from keeping their living quarters, houses and towers in good conditions through prohibitions and regulations. Many libraries were destroyed and lost forever.

There seems to have been a revival of Athonite monasticism in the late 1830s in that most of the ruling monasteries were busy repairing their buildings. The monks tried to raise money in every possible way - selling manuscripts to 'silly' travellers, of which Curzon was one. They also sold hazelnuts to Constantinople. Moreover, Vatopedi, for example, frequently accommodated up to five hundred guests, servants and tenants of the abbey who came on stated days to pay their rents and receive the benediction of the hegoumenos, as Curzon records. ${ }^{38}$

\footnotetext{
${ }^{37}$ Ibid., pp. 104.

${ }^{38}$ Ibid., pp. 105.
} 
According to Athelstan Riley's account, the idiorrhythmic way of life was common in many monasteries in the mid-nineteenth century, primarily initially for economic reasons.

They follow the idiorrhythmic rule, although they have several times endeavoured to change it to the cenobitic, but failed owing to their poverty. We were much surprised at hearing that the idiorrhythmic system was the more economical of the two. ... in this case each inmate cultivated his own little garden, and ... when they worked for themselves individually they accomplished more than when they laboured for the common weal. ${ }^{39}$

Riley also notes that all the ruling monasteries on the western side of the peninsula were cenobitic with the exception of Dochiariou, whereas on the eastern side all except Esphigmenou were idiorrhythmic. One reason for this difference could have been that the monasteries on the western side had farmland (metóchion) on the other two peninsulas Cassandra and Sithonia - and on the main land - as they have today.

The sea was less treacherous to the West and therefore it was much easier for the monasteries on that side to raise the extra funds and support needed to pay the sultan's continuous stream of new poll taxes. Moreover, the monasteries lost their farmland in Moldavia and Wallachia in 1865 when Alexander Curzon became the ruler of the united state (Romania) and confiscated all monastic land and properties. This particularly affected the monasteries on the eastern side, which had much land in that area.

Riley's account is especially revealing regarding changes in the monk population. St Panteleimon surpassed the three largest monasteries, Vatopedi, Iviron and Lavra, by far. Carlyle and Hunt counted 15 monks in St Panteleimon in 1801, whereas Curzon gave the figure of 130 in 1837. Then, fifty years later in 1883, Riley recorded 1,600 Russian monks on Athos, and half of them lived in St Panteleimon. When the servants were

\footnotetext{
${ }^{39}$ Ibid., pp. 108.
} 
included, the Russian population amounted to about two thousand, in other words nearly half of the entire monastic population. The increase in Russians on Athos was explosive. ${ }^{40}$ According to Riley, Russico, as St Panteleimon was known then, presented itself as a 'go-ahead colony'. The inhabitants pride themselves, he records,

upon being the subject of a first-class European Power and despise the Greek civilization as a relic of Oriental barbarism. The whole place is more like a small town than a monastery ... for all around it and down to the water's edge there are workshops, and storehouses, and dwelling houses; and still the monks are building more, so that the great monastery is increasing in extent year by year. ${ }^{41}$

Realizing that Russico was mainly a government affair supported by government money, Riley asked himself, 'what interests other than religion can Russia have at Mount Athos?' From his discussions with the Russian monks, he came to the conclusion that Athos was of primary importance to Russia in terms of extending her territory to the Mediterranean. Its acquisition would provide her with a practically unconquerable fortress in the midst of European Turkey, from where the conquering of Thessaloniki (then known as Salonica), a town second only to Constantinople in political importance, could be ensured by cutting off its transportation routes to Turkey. ${ }^{42}$

During these decades, there was also a steady increase in the numbers of Russian pilgrims to the extent that there were more Russians than Greeks in 1883. According to Riley, the Russian pilgrims heading to Constantinople were particularly attracted to a certain spiritual monk (pneumatikos) at St Panteleimon, who had the reputation of being a prophet directly inspired by God. The monk in question was undoubtedly the Elder Silouan (d. 1938), who became famous later through the writings of his disciple Fr Sophrony (d. 1994) and was canonized in 1988. St Silouan was one of the first monks to

\footnotetext{
${ }^{40}$ Ibid., pp. 109.

${ }^{41}$ Ibid., pp. 109.

${ }^{42}$ Ibid., pp. 109-110.
} 
sow the seed of renewal through Fr Sophrony and other Athonites in the twentieth century. ${ }^{43}$

The Russian monks received generous support from the Tsar and the Russian government - due to the many retired officers from the Russian army who were still in the prime of life and had first-hand contacts in the government. Thus, it was the Greek monasteries that found it difficult to pay their taxes. Consequently, the monasteries on the eastern side also had to change to the idiorrhythmic way of life in order to make ends meet.

Frederick William Husluck (d. 1920) provides an informative résumé and a slightly different interpretation of decline, crisis and change during Ottoman rule in his posthumously published work Athos and its Monasteries. He saw the year 1430, when Salonica fell to the Turks, as a turning point in the history of Athonite monasticism. At least two major changes in monastic conditions have their roots in that fall, namely the sultan's continuously increasing assessments and the idiorrhythmic way of monastic life. He attributes the rise of the idiorrhythmic system to the growth of wealth and renunciation among wealthy laymen, and not really to the imposed Turkish taxation system. He argues: It [the idiorrhythmic system] is obviously less economical, and a return to the coenobiac system is frequently one of the first steps taken to revive a decayed monastery ... Most of the abuses are traceable to the same relaxation in discipline which later brought about the idiorrhythmic system..$^{44}$

During the first years of my field research on Athos in the mid-1980s, when many monasteries still followed the idiorrhythmic rule, it was noticeable that the way of life in these monasteries was more prone to laxity of monastic morals than in the cenobitic

\footnotetext{
${ }^{43}$ Ibid., pp. 111-112.

${ }^{44}$ Ibid., pp. 117.
} 
monasteries. It is also true that the revival of Athonite monasticism in the nineteenth and twentieth centuries corresponded with the change to the cenobitic way of life.

The travellers' accounts give an equally good overview of the Slavs on Athos. It was during the reign of Stephan Dušan and the following centuries that many of the ruling monasteries were 'Serbianized': Serbians founded Simonopetra; St Paul was Serbianized and made independent of Xeropotamou; Chilandar, and also Gregoriou, Dionysiou and Dochiariou were Serbianized. Of these, St Paul's and Xenophontos, both of which were still Slavic in the seventeenth century, became Hellenized with the rise of the Phanariotes during the eighteenth century. The process of conversion then followed a pattern: rich Greeks bought up all the debt-ridden monasteries. This is how Russico, or St Panteleimon, also became a dependency of a phanariote family in the early nineteenth century.

The nine years of Turkish occupation on Athos (1821-1829) once again changed the nationalities at the monasteries. Most of the ruling monasteries were impoverished. St Panteleimon was ruined, but the Russians managed to buy it, and recolonized it in 1839. Twenty years later, they successfully paid off all of its outstanding debts, and in 1869, they were granted the privilege of using Russian in the services on alternative days.

An explosive Russianization of Athos began. The tactic was; first to purchase a 'monastic cottage' (kellion), then to enlarge it and exceed the lawful number of inmates on one pretext or another, and eventually to present a petition with strong diplomatic and pecuniary backing for the conversion of the kellion to a cenobitic skete (koinobiake skete), which although still a dependency was allowed to house more monks than its ruling monastery. This is how the Russians acquired the Skete of St Andrew. The Russians population in 1902 already totalled 3,496, whereas the Greek population numbered only 3,276. Given the 286 Romanians, 307 Bulgarians, 16 Serbs - a dramatic drop since the 
fifteenth century - and 51 Georgians, there were about 800 more Slavs than Greeks; the total Athos population then was 7,432. The second half of the nineteenth century was certainly an era of Russianization on Athos, not merely due to the expansion of the Russian population in the Kellia, but also due to Elder Ieromen and Archimandrite Makary's dynamic leadership of St Panteleimon. ${ }^{45}$

Fortune changed once again with the revolution in Russia: recruitment ceased altogether and the Russian population declined rapidly. The total population in 1912 was calculated as 7,754, falling to 6,345 in 1913 and further to 2,878 in 1943 . The main reason for the decline was the natural mortality of the Russians. ${ }^{46}$

The Greeks felt threatened by the presence of so many Russians and Slavs, who somewhat unexpectedly and rapidly had become the majority on what they considered to be their Holy Mountain. The Russians felt frustrated because they only had a single vote in the Holy Community despite being in the majority. The unstable political situation in the Balkans at the end of the nineteenth century eventually led to a massive attack on the Ottoman forces in Europe and to their withdrawal from Macedonia. Athos was finally liberated without a struggle on 15 November 1912 when the Turkish Aga vacated his office in Karyes, bringing to an end nearly five centuries -488 years to be exact - of Ottoman rule. ${ }^{47}$

In hindsight, one realizes that over the centuries the Athonite monasteries were founded, enlarged and rebuilt many times by benefactors from the various Slavic countries: only Pantokrator, Stavronikita, Philotheou, Lavra and Dionysiou were of Greek origin. It is also worth pointing out that benefactors from many countries, Greece included,

\footnotetext{
${ }^{45}$ Ibid., pp. 118-120. See also Archimandrite Sophrony, The Monk of Mount Athos (New York, 1973), p. 18.

${ }^{46}$ Gothóni, Tales, pp. 119.

${ }^{47}$ Speake, Mount Athos, pp. 157.
} 
have revived Athonite monasticism in times of severe economic and political crisis. The network of benefactors of the ruling monasteries has been and still is wide, covering Greece, all the Balkan countries as well as Russia, and nowadays the EU. ${ }^{48}$

\section{Famous Elders on the Holy Mountain}

The revitalization of Athonite monasticism in the nineteenth and twentieth centuries was closely connected with pilgrimage and travellers from the Balkans and Russia in particular. Revival, it seems, started in the caves, huts and hermitages on the mountain slopes down at the southern tip of the peninsula, the so-called desert of Athos. A number of gifted spiritual monks took up residence there, where many had lived for centuries, in the middle decades of the twentieth century. Groups of disciples began to gather around them, and these spiritual fathers began to attract pilgrims.

Although many of the ruling monasteries where near to closing due to a lack of novices, places such as New Skete were flourishing: creative effort regenerated spiritual life there, as has been the case on Athos throughout its history. I have already mentioned the spiritual revival of St Symeon the New Theologian in the eleventh century, St George of Sinai around 1300 and St Gregory Palamas in the mid-fourteenth century: all three spread the hesychastic tradition and created important links in the chain of spiritual struggle from the past to the future.

Athonite monasticism began to flourish in St Panteleimon and its dependencies from the mid-nineteenth until the beginning of the twentieth century despite the Ottoman presence on the peninsula. It was from Athos that the great revival in the Russian Church

\footnotetext{
${ }^{48}$ Gothóni, Tales, pp. 121.
} 
spread at the end of the eighteenth century. As is so often the case, dissatisfaction gave a fresh impetus, resulting in revival that has lasted for centuries.

Paisy Velichkovsky (d. 1794), a young student at the theological academy of Kiev who was frustrated by the secular tone of the teaching, left to become a monk on Athos in order to pursue his spiritual calling. He learned about the hesychast tradition and met his soul mate in monk Nicodemus, known later as St Nikodimos of the Holy Mountain, 'the Hagiorite' (d. 1809). With the help of St Makarios, Metropolitan of Corinth, he compiled the anthology of spiritual writings called the Philokalia (1782). This became a gigantic work in five volumes, containing sayings of the desert fathers from the fourth to the fifteenth century, dealing principally with the theory and practice of the Jesus Prayer. This anthology has proved to be one of the most influential publications in the Orthodox world. It is still widely read not only by monks, but also by many people. ${ }^{49}$

With great enthusiasm and energy, Paisy produced a Slavonic translation of the Philokalia, which was published in Moscow in 1793, just a decade later than the Greek original. He especially emphasized the importance of practising continual prayer - the Jesus Prayer - and the need for obedience to an elder or starets, as they were called in Russia. He never returned to Russia, but went to Romania in 1763 . He was appointed Abbot of the monastery of Niamets, which soon became a great spiritual centre with more than 500 brethren who gathered around him for advice on spiritual striving, and helped him with the work of translating the Greek Fathers into Slavonic.

The first well-known starets of nineteenth-century Russia was St Seraphim of Sarov (1759-1833). After sixteen years in the monastery of Sarov he lived in seclusion for nineteen years, first in a simple hut and then later in a monastery cell. In 1815, he felt

\footnotetext{
49 Timothy Ware, The Orthodox Church (London, 1964), p. 110. Kallistos Ware, The Inner Unity of the Philokalia and its influence in East and West (Athens, 2004), pp. 41-61.
} 
ready for the office of eldership, and opened his doors to pilgrims and visitors who came for help in both worldly and spiritual matters. He is regarded as a characteristically Russian saint, healing the sick, giving advice and answering visitors' questions even before they were asked, knowing what bothered them and what they needed. ${ }^{50}$

St Seraphim, it seems, had no teacher in his spiritual struggle, and he left no successor. After his death, some monks in the hermitage of Optino tried to follow his example, especially the elders Leonid (d. 1841), Macarius (d. 1860) and Ambrose (d. 1891). They all belonged to the school of Paisy, and all were devoted to the Jesus Prayer. The hermits of Optino influenced a number of Russian writers, notably Gogol, Dostoevsky and Tolstoy. Their works inspired numerous readers and lay people to embrace the spiritual atmosphere of the renowned elders.

The Zeitgeist of that time is well captured in the anonymous book The Way of a Pilgrim, which is about an ordinary Russian peasant who tramped from place to place in the countryside continuously practising the Jesus Prayer. This work is significant as a document of that time in that the story is about a peasant carrying in his rucksack a copy of the (presumably) Slavonic translation of Philokalia, which at the end of the nineteenth century was translated into Russian by St Theophan the Recluse (d. 1894). St John of Kronstadt (d. 1908) was also immensely influential during these years. It is evident from his autobiography My Life in Christ that he, too, possessed the gifts of healing and insight into spiritual struggle..$^{51}$

It is no exaggeration to state that there was a strong and widespread spiritual sentiment in Russia from the mid-nineteenth century onwards, and an eagerness to travel to famous monasteries such as Valamo on Lake Ladoga, but also as far as Jerusalem,

\footnotetext{
50 Timothy Ware, The Orthodox Church (London, 1993 [1963]), pp. 118.

${ }^{51}$ Ware, Orthodox Church, pp. 120-22.
} 
Constantinople and Athos. This pilgrimage movement became more organized after 1882, when the recently founded Imperial Orthodox Palestine Society made the arrangements. ${ }^{52}$ In hindsight, it seems that the revival of the Russian monastery of St Panteleimon was not at all surprising. There was a spiritual readiness in Russia from the mid-nineteenth century onwards, as reflected in the rapid rise in the number of monks in St Panteleimon. As in Russia, pilgrims were attracted to renowned elders, specifically St Silouan (18661938). He arrived in St Panteleimon in 1892, and some years later many people came to him for advice. His disciple and Archimandrite Sophrony (1896-1991) helped to build his reputation, not only among Russians but also among the other monks and pilgrims on Athos. St Panteleimon became a monastic town and the Skete of St Andrew in Karyes a huge monastery in merely half a century.

It is made clear in the first pages of Sophrony's book about Staretz Silouan how significant the wandering pilgrims in Russia were and how welcome they were as guests in Silouan's father's house. As a child Silouan soon became familiar with questions concerning the existence of God and the claim that Christ was not God: 'Where is this God of yours, then?' some visitors asked, and intrigued by this question Silouan decided to travel the world to look for God as soon as he became an adult. His search for an answer to this question eventually led him to Athos. He engaged in a spiritual battle, and after practising the Jesus Prayer for only three weeks, 'the prayer entered into his heart, to continue there, day and night, on its own accord'. ${ }^{53}$

Apart from being familiar with the blossoming religiosity of the wandering pilgrims in Russia, Silouan also learned about spiritual struggle from father Anatol, who had been a monk and acted as confessor at St Panteleimon for more than forty-five years.

\footnotetext{
${ }^{52}$ Nicholas Fennell, The Russians on Athos (Bern, 2001), p. 163.

${ }^{53}$ Sophrony, The Monk, pp. 8-19.
} 
Regarding the right way to pray father Anatol advised Silouan: 'When you pray, keep your mind quite, free from any imagining, any irrelevant thought. Enclose your mind in the words of your prayer'. ${ }^{54}$ Thus, Silouan encountered the hesychast tradition that he was to cherish for the rest of his life with great success.

Having been fortunate enough to live near Silouan, Sophrony was able to make notes on his teachings, which he then collected in the work, referred to previously. He also learned the practice of the Jesus prayer at first hand, and followed the hesychast tradition in a cell overlooking the sea and overhung by a sheer cliff near the ruling monastery of St Paul's, where he lived during the Second World War. Later he was renowned for having founded the monastery of St John the Baptist at Tolleshunt Knights in Essex, England, a monastery that is the most dynamic centre of Orthodox spirituality in Britain today. ${ }^{55}$

The revival also began elsewhere on Athos after the Second World War. A particularly dynamic brotherhood gathered around the renowned desert father Elder Joseph the Hesychast, also known as the Cave Dweller, during the 1950s. Like Staretz Silouan, in his spiritual struggle he emphasized inner prayer, the cultivation of inner recollection, stillness (hesychia) and the prayer of the heart. Throughout his life he followed St Paul's injunction, 'Praying without ceasing' (1 Thess. 5:17). In emphasizing inner prayer and stillness, Elder Joseph anticipated the rule that was to be adopted in the contemporary revival on Athos. ${ }^{56}$

Metropolitan Kallistos has characterized the revival as Philokalic and Palamite. It was partly inspired by Philokalia in that the prayer of the heart and the invocation of the

\footnotetext{
${ }^{54}$ Ibid., p. 25.

${ }^{55}$ Speake, Mount Athos, p. 174.

${ }^{56}$ Elder Joseph, Elder Joseph the Hesychast. Struggles - Experience - Teachings (Mount Athos, 1999), pp. 19-20.
} 
name of Jesus are at the very centre of the spiritual struggle. Palamas in turn, who successfully defended this hesychastic practice, became a special mentor for later Athonites who took up these practices as a rule for their spiritual life. ${ }^{57}$

After living many years in conditions of extreme privation at St Basil's, Elder Joseph settled at New Skete where he found fame as a teacher and spiritual father. His teaching was based on the cultivation of inner stillness (hesychia) and the prayer of the heart, which is the direction all leaders of the current Athonite revival have followed. Although he died in 1959, no fewer than six Athonite monasteries have been revived by his spiritual children, who include Fr Ephraim, later the abbot of Philotheou, Fr Charalambas, abbot of Dionysiou, and Elder Joseph of Vatopedi, who was one of the leading lights in its and remains its principal spiritual father. ${ }^{58}$

Fr Vasileios Gontikakis was living as a hermit in a cell attached to Vatopedi in 1960s, when Stavronikita had been abandoned. The civil governor invited him to become its abbot in 1968, an invitation he accepted. Together with some disciples, he revived the deserted monastery. He then moved to Iviron, reviving that monastery as well, which like Stavronikita readopted the cenobitic way of life.

The 1970s saw the revival of two other monasteries: Philotheou through Fr Ephraim from New Skete, and Simonopetra through Fr Aimilianos, who moved to Athos from Meteora with his disciples and was somewhat inspired by the late St Silouan. This revival trend has continued and it persists in most of the ruling monasteries. Following in the footsteps of Fr George Kapsanis, who became abbot of Gregoriou, most of the abbots started to write books to the extent that there is now a flourishing Athonite literature on the most charismatic and inventive fathers of the last century.

\footnotetext{
${ }^{57}$ Ibid., p. 175.

${ }^{58}$ Ibid., p. 175 .
} 


\section{Summary}

Table 3 gives a graphical summary of pilgrimage and the becoming of Athonite monasticism from a theoretical perspective.

Table 3 Pilgrimage and the becoming of Athonite monasticism

Past Before The given time After Future

St John Climacus St Maximos Kafsokalyvian St Silouan

St Gregory Palamas $\quad$ Elder Joseph

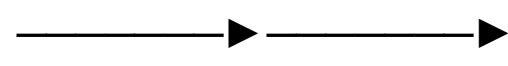

St Symeon the New Theologian

St George of Sinai

Philokalia
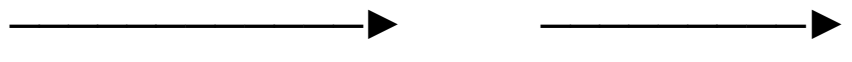

hesychasm

This historical perspective shows how, during the five centuries of Ottoman rule, the hesychastic tradition was linked to charismatic fathers and pilgrims in periods of decline, crisis and change. These fathers and pilgrims economically and spiritually revitalized Athonite monasticism, starting a tradition that has continued from the ancient past until the present time, and is still today a work-in-progress. 


\section{Bibliography}

Climacus, John, The Ladder of Divine Ascent (New York: Paulist Press, 1982).

Dvornik, Francis, The Photian Schism: History and Legend (Cambridge: Cambridge University Press, 1948).

Elder Paisios of Mount Athos. Spiritual Counsels I. With Pain and Love for Contemporary Man (Thessaloniki: Holy Monastery "Evangelist John the Theologian", 2007).

Fennell, Nicholas, The Russians on Athos (Bern: Peter Lang, 2001).

Gothóni, René, Paradise within Reach. Monasticism and Pilgrimage on Mt Athos (Helsinki: Helsinki University Press, 1993).

Gothóni, René, Tales and Truth. Pilgrimage on Mount Athos Past and Present (Helsinki: Helsinki University Press, 1994).

Gothóni, René, Attitudes and Interpretations in Comparative Religion. FF Communications, 272 (Helsinki: Academia Scientiarum Fennica, 2000).

Gothóni, René, 'Mount Athos During the Last Centuries of Byzantium', in Jan Olof Rosenqvist (ed.), Interaction and Isolation in Late Byzantine Culture. Papers Read at a Colloquium Held at the Swedish Research Institute in Istanbul, 1-5 December 1999 (Uppsala: Swedish Research Institute in Istanbul, 2004), pp. 57-69.

Joseph, Elder, Elder Joseph the Hesychast. Struggles - Experience - Teachings (Mount Athos: The Great and Holy Monastery of Vatopedi, 1999).

Kallistos of Diokleia, The Power of the Name. The Jesus Prayer in Orthodox Spirituality (Oxford: SLG Press, 2000). 
Konidaris, Ioannis M., The Mount Athos Avaton (Athens: Ant. N. Sakkoulas Publishers, 2003)

Korablev, B. (ed.), Actes de Chilandar II [Actes de l'Athos $5=V V 19$ (1912; pr. 1915)] (repr. Amsterdam, 1975), no. 53, 84, 93, 99, 106-107, 112, 117.

Lemerle, P., Guillou, A., Svoronos, N., Papachryssanthou, D. (eds), Actes de Lavra II [Archives de l'Athos 8] (Paris, 1977), no. 88, 10-11.

Meyendorff, John, A Study of Gregory Palamas (second edition, Crestwood NY: St Vladimir's Seminary Press, 1998).

Ostrogorsky, George, History of the Byzantine State (Oxford: Blackwell, 1968).

Sophrony, Archimandrite, The Monk of Mount Athos (Crestwood, NY: St Vladimir's Seminary Press, 1973).

Speake, Graham, Mount Athos: Renewal in Paradise (New Haven and London: Yale University Press, 2002).

Talbot, Alice-Mary, 'Women and Mount Athos', in Anthony Bryer and Mary Cunningham (eds), Mount Athos and Byzantine Monasticism. Publication for the Society for the Promotion of Byzantine Studies, 4 (Aldershot: Asgate, 1996).

Ware, Timothy, The Orthodox Church (London: Penguin Books, 1964).

Ware, Kallistos, 'St Maximos of Kapsokalyvia and Fourteenth-Century Ayhonite Hesychasm', in Kathigitria: Essays Presented to Joan Hussey on her $80^{\text {th }}$ Birthday (London, 1988).

Ware, Timothy, The Orthodox Church (London: Penguin Books, 1993)

Ware, Bishop Kallistos, The Inner Kingdom. Volume 1 of the collected works (Crestwood, NY: St Vladimir's Seminary Press, 2001). 
Ware, Kallistos, The Inner Unity of the Philokalia and its influence in East and West (Athens; Alexander S. Onassis Public Benefit Foundation, 2004), pp.41-61.

Wittgenstein, Ludwig, Philosophische Untersuchungen (Oxford: Blackwell, 1967).

Živojinović, Mirjana, 'De nouveau sur le séjour de l'empereur Dušan à l'Athos', Zbornik Radova Vizantoloskog Instituta, 21 (1982): 119-126. 